\title{
PENGEMBANGAN MESIN TEKNOLOGI TEPAT GUNA PEMBUAT AYAM GORENG POK - POK BAGI UMKM DI SURABAYA BARAT
}

\author{
Slamet Riyadi' ${ }^{1}$ M. Syaiful Hudan ${ }^{2}$, Erik Rahmatun Akbar ${ }^{3}$ \\ ${ }^{1}$ Universitas Wijaya Putra \\ ${ }^{2}$ Universitas Wijaya Putra \\ ${ }^{3}$ Universitas Wijaya Putra \\ slametriyadi@uwp.ac.id,14321037@students.uwp.ac.id,14321023@students.uwp.ac.id
}

\begin{abstract}
Abstrak
Daging ayam pedaging merupakan salah satu komoditi unggas yang memberikan kontribusi besar dalam memenuhi kebutuhan protein asal hewani bagi masyarakat Indonesia. Kebutuhan daging ayam setiap tahunnya mengalami peningkatan, karena harganya yang terjangkau oleh semua kalangan masyarakat. Penggorengan merupakan salah satu aktivitas penting yang sudah lama dilkukan dan banyak dijumpai dalam industri pengolahan pangan, baik industri berskala kecil maupun industri pangan berskala besar. Penggorengan berlangsung secara konduksi melalui kontak langsung antara permukaan dinding pemanas dengan produk yang digoreng. Cara seperti ini proses transfer panasnya dianggap kurang efisien karena luas permukaan konduksi terbatas hanya pada dinding pemanas yang bersinggungan dengan produk yang digoreng. Permasalahan yang ada pada UMKM: 1) masih cara manual/tradisional, 2) produksi rendah dan permintaan banyak, 3) penjualan dan pemasaran masih standart, 4) Rasa kurang empuk/padat. Metode pelaksanaan: Metode pengorengan dengan menggunakan otomasi Mesin Teknologi Tepat Guna dengan media penghantar panas minyak goreng lebih menguntungkan karena selain luas permukaan kontak panas meningkat juga proses transfer panasnya berlangsung secara konduksi dan konveksi. Hasil pengabdian ini: meningkatkan produksi dan pendapatan karena menggunakan otomasi tekonologi mesin tepat guna karena melebarkan pemasaran. Metode pengabdian berupa pelatihan teknologi mesin ayam goreng pok-pok. Sedangkan hasil pengabdian ini UMKM juga mengimplementasikan otomasi mesin teknologi guna agar harga selalu terjangkau, produksi meningkat $100 \%$.
\end{abstract}

Kata Kunci : teknologi tepat guna, ayam goreng pok-pok, umkm

\section{PENDAHULUAN}

Secara ekonomi, Indonesia merupakan Negara berkembang. Seiring dengan naiknya pendapatan perkapita penduduk, maka kebutuhan akan protein hewani bagi masyarakat juga meningkat. Daging ayam pedaging merupakan salah satu komoditi unggas yang memberikan kontribusi besar dalam memenuhi kebutuhan protein asal hewani bagi masyarakat Indonesia. Kebutuhan daging ayam setiap tahunnya mengalami peningkatan, karena harganya yang terjangkau oleh semua kalangan masyarakat.. Broiler adalah jenis ternak unggas yang memiliki laju pertumbuhan yang sangat cepat, karena dapat dipanen pada umur 5 minggu.Keunggulan broiler didukung oleh sifat genetik dan keadaan lingkungan yang meliputi makanan, temperatur lingkungan, dan pemeliharaan. Penampilan ayam pedaging yang bagus dapat dicapai dengan sistem peternakan intensif modern yang bercirikan pemakaian bibit unggul, pakan

$$
\text { Teknologi Tepat Guna } \quad 248
$$


berkualitas, serta perkandangan yang memperhatikan aspek kenyamanan dan kesehatan ternak.

Penggorengan merupakan salah satu aktivitas penting yang sudah lama dilkukan dan banyak dijumpai dalam industri pengolahan pangan, baik industri berskala kecil maupun industri pangan berskala besar. Meskipun penggorengan merupakan proses pemasakan pangan yang sudah lama dilakukan, tetapi proses tersebut banyak yang belum diungkap secara ilmiah. Penggorengan tanpa minyak lazim disebut penyangraian, penggorengan seperti ini proses pemanasan berlangsung secara konduksi melalui kontak langsung antara permukaan dinding pemanas dengan produk yang digoreng. Cara seperti ini proses transfer panasnya dianggap kurang efisien karena luas permukaan konduksi terbatas hanya pada dinding pemanas yang bersinggungan dengan produk yang digoreng. Guna meningkatkan efisiensi proses transfer panas selama penggorengan maka luas permukaan transfer panasnya perlu ditingkatkan melalui penggunaan media penghatar panas berupa butiran bahan padat (pasir, kerikil, atau bahan lain berwujud butiran dan mempunyai nilai konduktivitas panas besar). Metode penggorengan dengan menggunakan media penghantar panas bahan padat butiran lebih menguntungkan karena selain luas permukaan kontak panas meningkat juga proses transfer panasnya berlangsung secara konduksi dan konveksi. Penggorengan kerupuk dengan pasir telah dilakukan dibeberapa daerah di Indonesia, namun sampai saat ini kajian secara ilmiah melalui bentuk penelitian, serta pengembangan untuk diaplikasikan pada penggorengan produk-produk pertanian yang lain masih sulit ditemukan. (Siswantoro dkk 2014)

Mengacu dari keadaan ini, maka dirancang suatu mesin berupa Mesin Teknologi Tepat Guna Pembuat Ayam Goreng Pok - Pok Bagi Umkm Di Surabaya Barat. Dengan dibuatnya alat ini diharapkan proses pengerjaan pembuatan mesin pengiris ubi dapat dengan cepat, mudah dan efisien waktu. Dengan pembuatan alat ini semoga dapat membantu industri-industri kecil rumah tangga untuk meningkatkan hasil produksinya baik secara kuantitas maupun kualitas. Tujuan dari perancangan alat ini untuk membuat prototype mesin pengiris ubi dengan penggerak motor listrik kapasitas $30 \mathrm{~kg} / \mathrm{jam}$ yang dapat digunakan untuk UKM rumah tangga yang memproduksi keripik ubi dengan kapasitas besar dan hasil irisan yang lebih baik dibandingkan pengerjaan manual. (Sajuli dan Hajar, 2017 )

\section{METODE}

Diagram alir pembuatan mesin pembuat makanan ayam pok - pok dengan sistem pneumatik seperti di bawah ini :

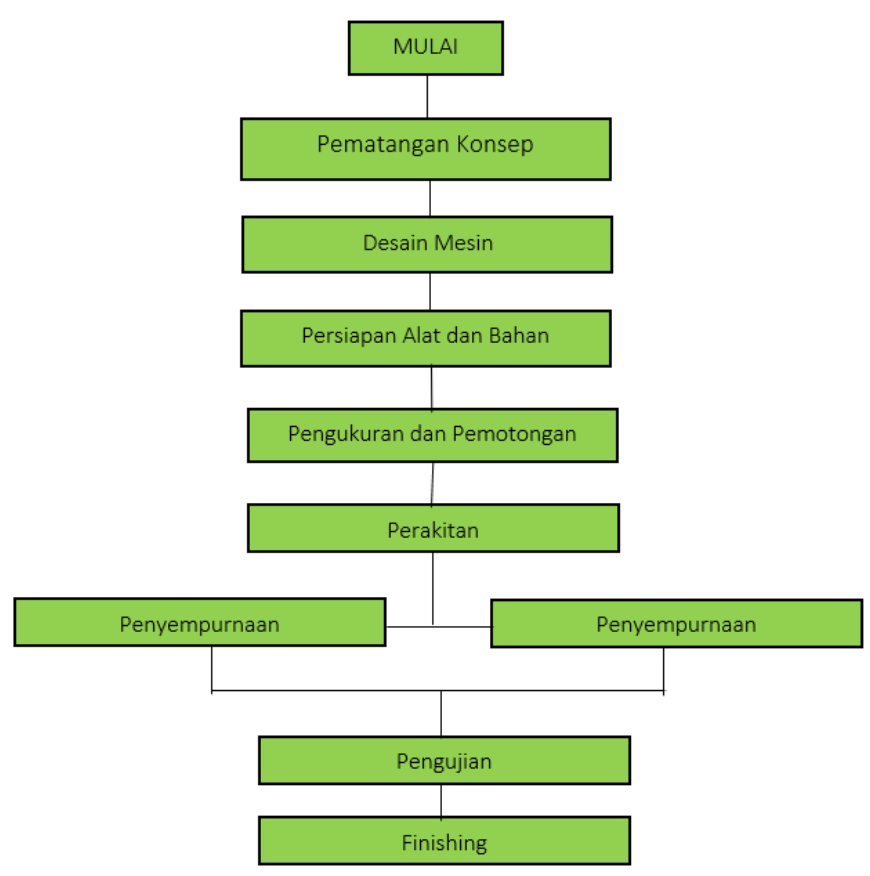

Gambar 1 : Diagram alur sistem pneumatik mesin pembuat makanan ayam pok - pok.

\section{Konsep dan Desain Mesin}

Sebelum memulai pengerjaan sebuah mesin pembuat makanan ayam pok - pok penulis harus memikirkan konsep yang ada di mesin tersebut. Dengan begitu semua proses pembuatan akan menjadi lebih mudah dan teratur. Konsep merupakan dasar dari pengerjaan mesin pembuat makanan ayam pok - pok. Setelah menemukan konsep yang sempurna untuk mesin pembuat makanan ayam pok - pok, maka kami menggambarkannya berupa desain mesin pembuat ayam pok - pok. Desain ini yang menjadi acuan dari semua yang dibutuhkan untuk membuat mesin pembuat makanan ayam pok - pok.

Teknologi Tepat Guna 


\section{Persiapan Alat Dan Bahan}

Sebelum memasuki proses pengerjaan mesin terlebih dahulu penulis harus menyiapkan alat dan bahan yang dibutuhkan untuk membuat mesin tersebut. Alat yang dibutuhkan harus sesuai fugsinya supaya pengerjaan kita tidak terhambat, dan bahan juga harus sesuai dengan kebutuhan mesin yang kita butuhkan.

\section{Pengukuran Dan Pemotongan}

Setelah alat dan bahan sudah terkumpul di lakukan pengukuran bahan baku, agar saat proses pengerjaannya tidak terjadi kesalahan dan jangan sampai salah pada proses pengukurannya karena akan menghambat proses pengerjaan mesin. Setelah semua bahan diukur denga teliti langkah selanjutnya adalah pemotongan bahan dengan menggunakan alat potong sesui bahan dan fungsinya.

\section{Perkitan}

Jiika bahan baku semua sudah siap maka kita siapkan peralatan pendukung untuk proses perakitan bahan baku satu persatu, dari pembentukan hingga pengelasan, komponen penggerak dan komponen lainnya sesuai dengan gambar diagram alur pengerjaan mesin.

\section{Pengujian Mesin Pembuat Makanan Ayam Pok - Pok}

Setelah baham baku dirakit semua sesai gambar desain yang penulis buat, disini penulis harus melakukan pengujian. Pengujian ini bertujuan untuk mengetahui kinerja dari mesin pembuat makanan ayam pok - pok sudah sempurna atau masih tidak.

Kerangka mesin pembuat makanan ayam pok - pok adalah bagian dari mesin pembuat makanan ayam pok - pok yang berguana sebagai penyangga komponen - komponen sehingga menjadi kokoh. Secara konstruksi mesin pembuat makanan ayam pok - pok tidak mengalami perubahan bentuk pada saat dilakukan pemindahan, guncangan dan hal - hal lain yang dapat menyebabkan terganggunya fungsi mesin pembuat makanan ayam pok - pok dan timbulnya peruahan settingan sistem. Pada gambar 5 dibawah ini adalah gambar dari kerangka mesin pembuat makanan ayam pok - pok :

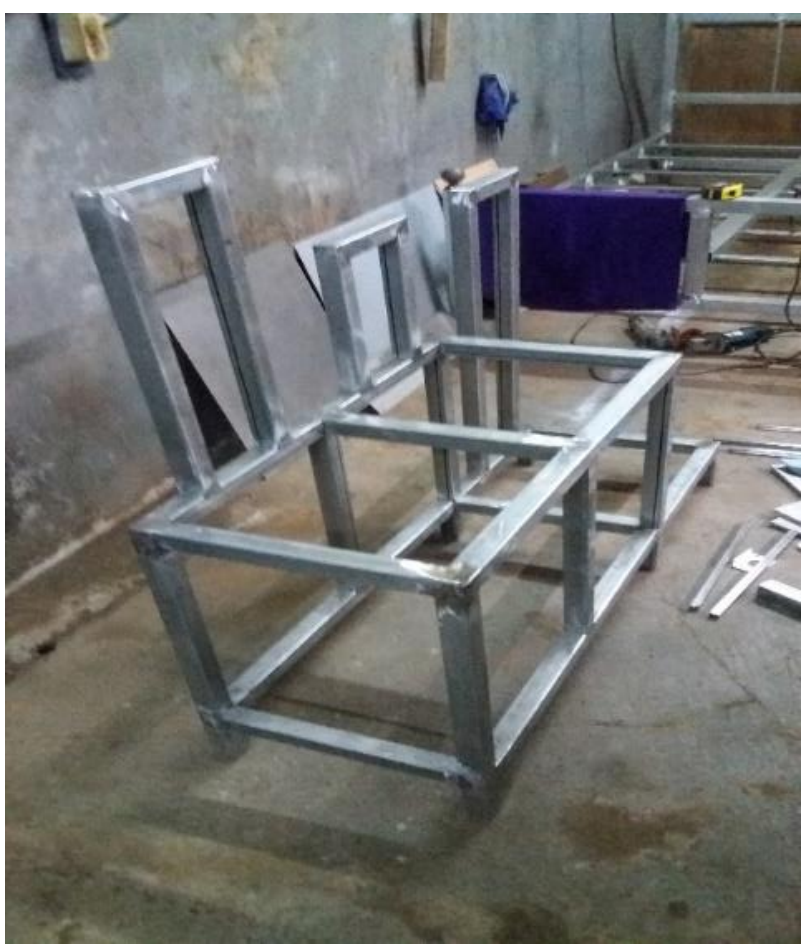

Gambar 2 : kerangka mesin pembuat makanan ayam pok - pok.

Gambar nomor 2 diatas adalah gambar kerangka mesin pembuat makanan ayam pok - pok sebelum proses pengecatan dan pemasangan bahan. Pada proses pembuatan rangka pada gambar nomor $5 \mathrm{kami}$ harus dituntut teliti dalam proses pembuatannya. Karena proses ini adalah proses yang sangat menentukan atau sangat penting untuk proses proses selanjutnya. 


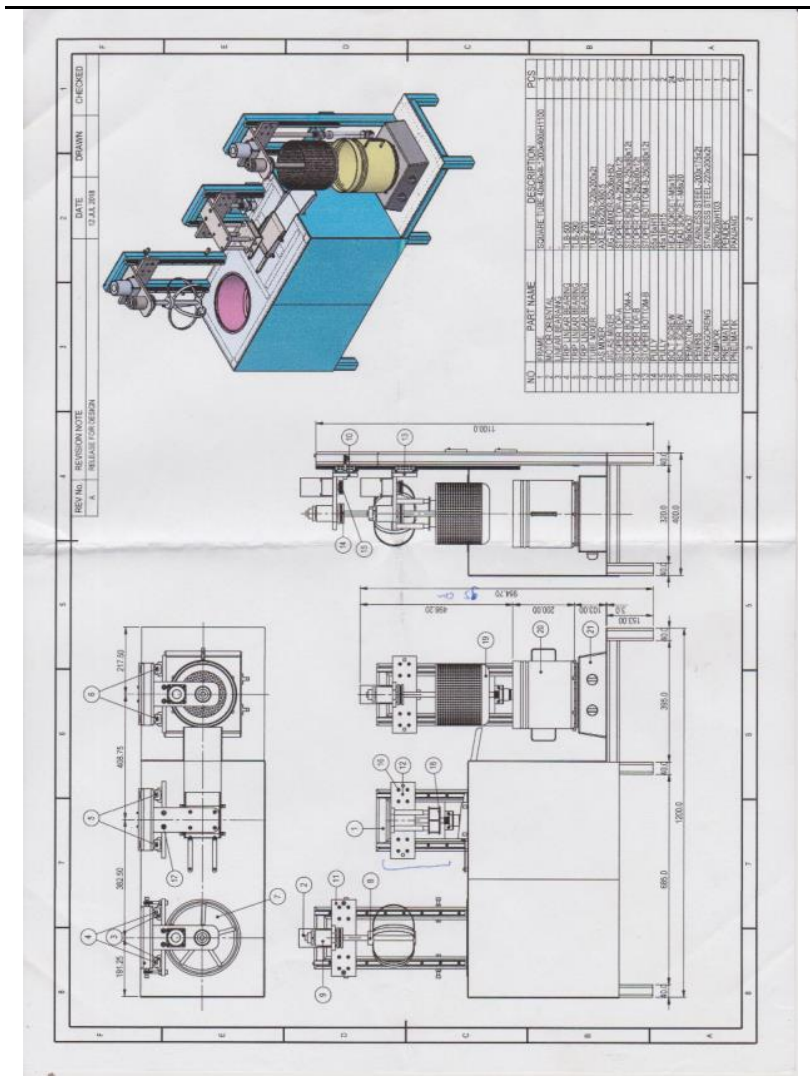

Gambar 3. Desain Mesin Pembuat Makanan Ayam Pok - Pok

\section{HASIL DAN PEMBAHASAN}

\section{Proses Pemotongan}

Sebelum terjadinya proses pemotongan pneumatik akan melakukan sedikit tekanan pada daging ayam supaya hasil potongan ayam akan sempurna dan rapi. Saat proses penekanan terjadi terdapat persamaan yaitu : $\mathrm{P}=\mathrm{F} / \mathrm{A}$

Dimana P ( tekanan ) yang dihasilkan dari kompresor dengan satuan Psi ( Pounds per Square Inch ) yang harus kita rubah ke satuan $\mathrm{N} / \mathrm{m}^{\wedge} 2$ ( newton per meter kuadrat ).

\section{Psi=6.894,76 N/m^2}

Untuk menghasilkan potongan yang sempurna dan rapi kami melakukan beberapa percobaan dengan memberikan tekanan yang berbeda - beda dan menghitung waktu yang dibutuhkan untuk menekan dan memotong adonan daging ayam tersebut.
Tabel $1:$ tabel benda kerja proses pemotongan pada mesin pembuat makanan ayam pok - pok.

\begin{tabular}{|c|c|c|}
\hline Tekanan & Waktu & Hasil \\
\hline 5 Psi & 30 secon & Gagal \\
\hline 10 Psi & 23 secon & Gagal \\
\hline 15 Psi & 17 secon & Berhasil \\
\hline 20 Psi & 10 secon & Berhasil \\
\hline 25 Psi & 5 secon & Berhasil \\
\hline
\end{tabular}

\section{Proses Pendorong}

Setelah proses pemotongan maka adonan yang sudah terpotong secara rapi dan sempurna akan didorong dengan sistem pneumatik ke dalam proses penggorengan. Dalam proses pendorongan kami menggunakan diameter tabung yang sama seperti pada proses pemotongan yang diketahui $\mathrm{D}=20 \mathrm{~cm}$. Untuk melakukan proses pemotongan kami melakukan beberapa survei untuk bisa menentukan waktu dan tekanan yang sempurna supaya adonan yang sudah terpotong rapi bisa terdorong ke tahap selanjutnya.

Tabel 2. benda kerja proses pendorongan adonan ke proses penggorengan pada mesin pembuat makanan ayam pok - pok.

\begin{tabular}{|c|l|}
\hline Tekanan & HaHasil \\
\hline 5 Psi & Gagal \\
\hline 10 Psi & Gagal \\
\hline 15 Psi & Gagal \\
\hline 20 Psi & Berhasil \\
\hline 25 Psi & Berhasil \\
\hline
\end{tabular}

\section{Proses Penirisan}

Setelah proses pemotongan maka adonan yang sudah terpotong secara rapi dan sempurna akan didorong dengan sistem pneumatik ke dalam proses penggorengan. Setelah proses penggorengan pneumatik akan melakukan proses pengangkatan bahan jadi untuk ditiriskan. Dalam proses penirisan kami menggunakan diameter tabung yang tidak sama dengan dua proses sebelumnya. Di proses penirisan kami menggunakan diameter cylinder pneumatik yang $\mathrm{D}=25 \mathrm{~cm}$. Dalam proses ini kami akan menghitung gaya piston yang terjadi saat proses penirisan dengan tekanan 10 Psi. 


\section{Kebutuhan Udara Pada Tabung Pneumatik Dalam Mesin Pembuat Makanan Ayam Pok - Pok}

Untuk dapat menghitung kebutuhan udara pada 3 pneumatik dalam mesin pembuat makanan ayam pok - pok kita memerlukan persamaan sebagai berikut :

Untuk pneumatik 1 yang terdapat pada proses pemotongan :

Kebutuhan udara=perbandingan kompresi $\mathrm{x}$ luas penampang piston $\mathrm{x}$ panjang langkah

Dimana :

Kebutuhan udara $=\quad(1,031+$ tekanan kerja (bar))/1,031 x luas penampang piston $\mathrm{x}$ panjang langkah

Kebutuhan udara $=((1,031+15) / 1,031) \quad \mathrm{x} 0,00972$ $\mathrm{m}^{\wedge} 2 \times 0,05 \mathrm{~m}$

Kebutuhan udara $=15,5 \times 0,0097 \mathrm{~m}^{\wedge} 2 \times 0,05 \mathrm{~m}$

Kebutuhan udara $=0,0075$ 1/menit

Untuk pneumatik 2 yang terdapat pada proses pendorongan

Kebutuhan udara=perbandingan kompresi $\mathrm{x}$ luas penampang piston $\mathrm{x}$ panjang langkah

Dimana :

Kebutuhan udara $=\quad(1,031+$ tekanan kerja (bar)) $/ 1,031$ x luas penampang piston $\mathrm{x}$ panjang langkah

Kebutuhan udara $=((1,031+25) / 1,031) \quad \mathrm{x} 0,00972$ $\mathrm{m}^{\wedge} 2 \times 0,15 \mathrm{~m}$

Kebutuhan udara $=25,2 \times 0,0097 \mathrm{~m}^{\wedge} 2 \times 0,15 \mathrm{~m}$

Kebutuhan udara $=0,036$ 1/menit

Untuk pneumatik yang terdapat pada proses peniris Kebutuhan udara=perbandingan kompresi $\mathrm{x}$ luas penampang piston $\mathrm{x}$ panjang langkah

Dimana :

Kebutuhan udara $=\quad(1,031+$ tekanan kerja (bar))/1,031 x luas penampang piston $\mathrm{x}$ panjang langkah

Kebutuhan udara $=((1,031+25) / 1,031) \quad \mathrm{x} \quad 0,00972$ $\mathrm{m}^{\wedge} 2 \times 0,2 \mathrm{~m}$

Kebutuhan udara $=25,24 \times 0,0097 \mathrm{~m}^{\wedge} 2 \times 0,2 \mathrm{~m}$

\section{Proses sistem Kerja Pneumatik Dalam Mesin Pembuat Makanan Ayam Pok - Pok Supaya Bisa Berjalan Maksimal}

Pada hal ini tentang memanfaatkan sistem kerja pneumatik secara maksimal dan menerapkan pada mesin pembuat ayam pok - pok. Untuk mendapatkan sistem kerja pneumatik yang maksimal kami menggunakan beberapa komponen yang bisa mendukung sistem kerja pneumatik secara maksimal. Berikut adalah komponen pendukung sistem pneumatik :

1. Kompresor

2. Katub control

3. Timer menegement

4. Sensor proxy

Semua komponen diatas menggunakan diagram alur. fungsi dan kegunaan dalam mesin kami yaitu mesin pembuat makanan ayam pok - pok.

Dimulai dari kompresor yang terdapat pada mesin pembuat makanan ayam pok - pok yang dipakai. Kompresor yang dipakai adalah kompresor potable pada umunya. Untuk menentukan tekanan yang diperlukan kami melakukan beberapa survey. pengguna tidak perlu membutuhkan ruang yang banyak, tegangan listrik tidak telalu tinggi, dan menghemat biaya. Kompresor portable juga memudahkan pengguna untuk memindahkannya jika terjadi sesuatu hal.

Katub kontrol yang terdapat pada mesin pembuat ayam pok - pok. Kami menggunakan katub kontrol popet atau katub kontrol duduk yang tipe 2/2 sederhana pada umunya. Dengan mengunkan katub ini kami bisa mengontrol keluar masuknya udara yang ada tabung pneumatik. Kami bisa mengontrolnya sesuai keinginan dan kebutuhan mesin kami. Dengan begitu kinerja sistem pneumatik yang ada di mesin kami bisa maksimal dan sempurna.

Timer menegement yang terdapat pada mesin pembuat ayam pok - pok. Kami menggunakan timer menegement untuk memudahkan semua proses yang terjadi pada sistem pneumatik di mesin pembuat makanan ayam pok - pok. Dengan menggunakan timer menegement kita selaku pengguna sudah tidak perlu repot - repot untuk mengatur waktu yang dibutuhkan dalam sebuah proses yang terjadi pada mesin pembuat ayam pok - pok. hanya perlu mengatur waktu yang kita butuhkan dalam satu proses. Yang nantinya timer menegement akan mengontak sensor proxy untuk melakukan langkah atau step selanjutnya. Semua proses sistem

$$
\text { Teknologi Tepat Guna } \quad 252
$$


pneumatik yang terdapat pada mesin pembuat ayam pok - pok di kontrol dari panel kontrol yang terdapat didalam mesin pembuat makanan ayam pok - pok.

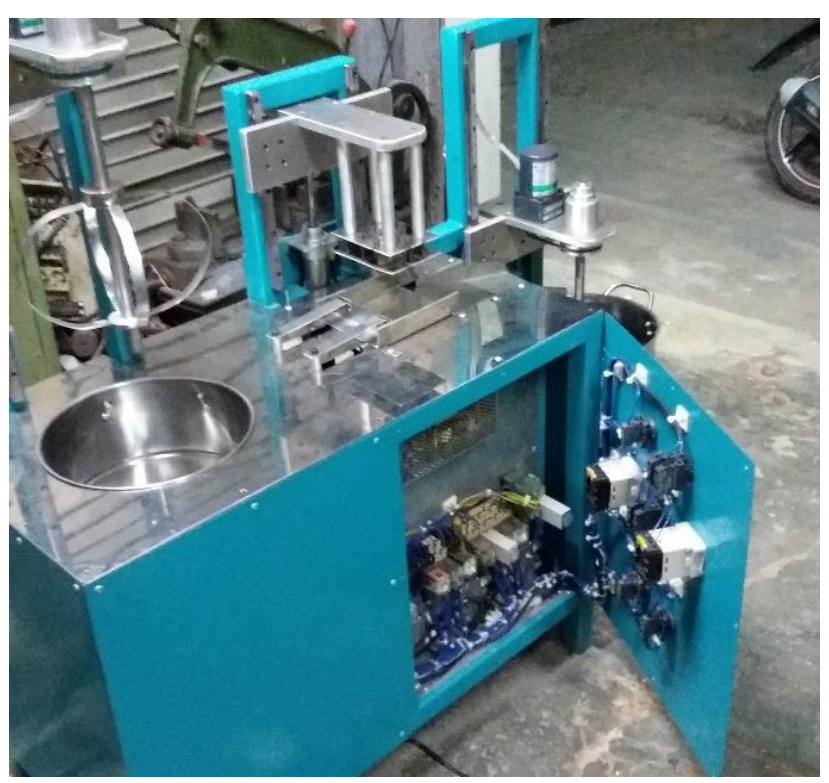

Gambar 4. Mesin Pembuat Ayam Pok - Pok

\section{Proses Perakitan}

Proses perakitan merupakan tahap terakhir dalam proses perancangan dan pembuatan suatu mesin tempe atau alat . dimana suatu cara atau tindakan untuk menempatkan dan memasang bagian-bagian dari suatu komponen mesin pengiris tempe yang digabung dari satu kesatuan menurut pasangannya. Sehingga akan menjadi perakit mesin yang siap digunakan sesuai fungsi yang direncanakan. Sebelum melakukaan perakitan hendaknya memperhatikan beberapa hal sebagai berikut :

1. Komponen - komponen yang akan dirakit telah selesai dikerjakan dan telah siap ukuran sesuai perencaan

2. Komponen - komponen standart siap pakai atau dipasangkan

3. Mengetahui jumlah yang akan dirakit dan mengetahui cara pemasangannya

4. Mengetahui tempat dan urutan pemasangan dari masing - masing komponen yang tersedia

5. Menyiapkan semua alat - alat bantu proses perakitan.
Komponen - komponen sistem pneumatik dari mesin pembuat makanan ayam pok - pok adalah sebagai berikut :
a. Plat stainless stell $1 \mathrm{~mm}$ dan $1,5 \mathrm{~mm}$
b. Kompresor
c. Tabung pneumatik
d. Selang angin pneumatik
e. Sensor proxy
f. Linier
g. Valve atau katub kontrol
h. Timer management
i. Kompor
j. Pisau
k. Tabung LPG $3 \mathrm{~kg}$

Berikut adalah langkah - langkah perakitan :
a. Menyiapkan kerangka
b. Memasang pneumatik dan instalasinya
c. Memasang pisau
d. Memasang kompor

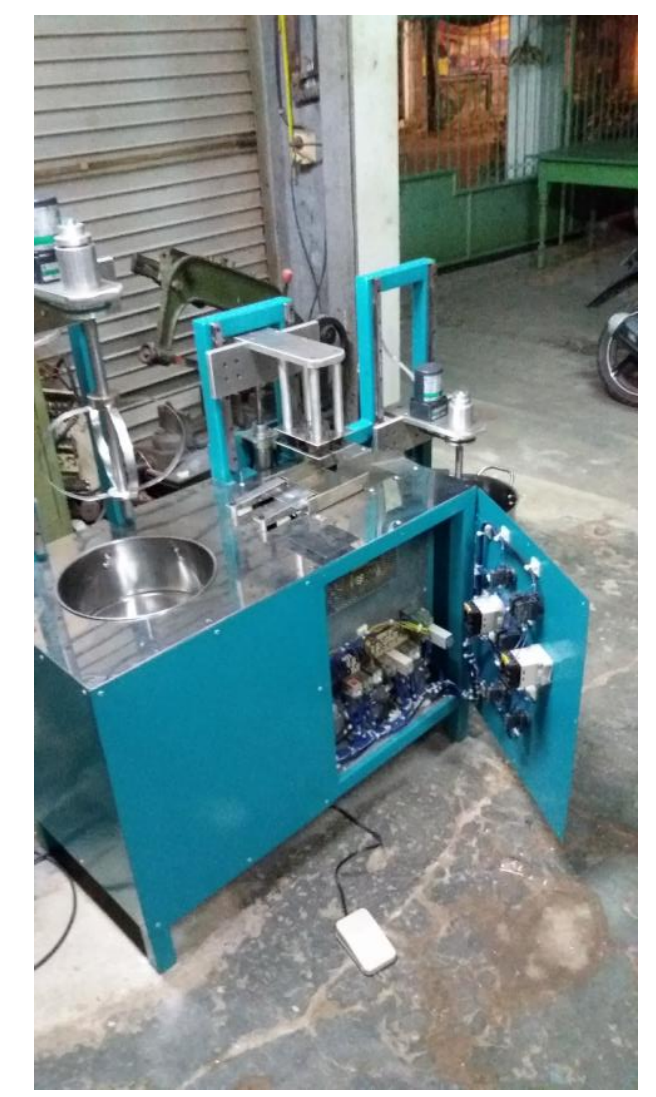

Gambar 5. Instalasi Listrik Mesin Pembuat Makanan Ayam Pok - Pok

Teknologi Tepat Guna 


\section{Perhitungan Biaya Produksi Dan Biaya Operator}

Perhitungan seluruh proses biaya produksi dan biaya operator secara rinci. Perhitungan tersebut nantinya digunakan untuk menentukan harga suatu produk. Penentuan harga mesin dapat dilihat pada gambar 11 tabel perhitungan biaya produksi dan biaya operator pada mesin pembuat makanan ayam pok - pok :

\begin{tabular}{|c|c|c|c|c|}
\hline Nomor & Nama Barang & Jumlah & Satuan (Rp) & $\begin{array}{c}\text { Harga Jumlah } \\
\text { (RP) }\end{array}$ \\
\hline 1 & Kompor & 1 & Rp. 100.000 & Rp. 100.000 \\
\hline 2 & Tabung pneumatik & 3 & Rp. 2.500 .000 & Rp.7.500.000 \\
\hline 3 & Kompresor & 1 & Rp.850.000 & Rp.850.000 \\
\hline 4 & Sensor proxy & 3 & Rp.200.000 & Rp.600.000 \\
\hline 5 & Plat stainless & 2 lembar & Rp.500.000 & Rp.1.000.000 \\
\hline 6 & pisau & 4 buah & Rp.20.000 & Rp. 80.000 \\
\hline 7 & Selang angin pneumatik & 3 meter & Rp.20.000 & Rp.60.000 \\
\hline 8 & Valve & 3 buah & Rp.20.000 & Rp.60.000 \\
\hline 9 & Timer management & 3 buah & Rp. 150.000 & Rp.450.000 \\
\hline 10 & Tabung LPG 3 Kg & 1 & Rp.50.000 & Rp.50.000 \\
\hline 11 & Motor & 2 & Rp. 2500.000 & Rp.5.000.000 \\
\hline 12 & $\mathrm{~V}-$ belt & 2 & Rp.100.000 & Rp.200.000 \\
\hline \multirow[t]{2}{*}{13} & Biaya pemasangan & & & Rp.8.000.000 \\
\hline & Jumlah Total & & & Rp.23.950.000 \\
\hline
\end{tabular}

\section{KESIMPULAN}

Kesimpulan berisi rangkuman hasil kegiatan pengabdian kepada masyarakat dan implikasi dari kegiatan yang dilaksanakan sebagai berikut :

1. Untuk melakukan pemotongan daging ayam

2. Mekanisme gaya yang dikeluarkan pada pneumatik untuk mendorong daging yang sudah terpotong ke dalam wajan penggorengan

3. Mekanisme tekanan pada pneumatik yang diberikan supaya saringan terangkat saat daging ayam sudah matang dengan timer yang sudah ditentukan

Saran

1. Untuk mendapatkan hasil pemotongan yang maksimal hendaknya beban tekanan yang diberikan harus sesuai dengan yang dibutuhkan atau mengikuti ketebalan dari benda kerja.

2. Letak pisau potong harus lebih presisi dan tajam, supaya pada saat pemotongan tidak terdapat sisa pemotongan

3. Timer yang digunakan untuk proses pengangkatan setelah penggorengan harus sesuai dengan kebutuhan supaya hasil yang diperoleh bisa sempurna

\section{UCAPAN TERIMAKASIH (Bila ada)}

Ucapan terimakasih disampaikan kepada Fakultas Teknik Universitas Wijaya Putra yang telah memberikan kontribusi dalampelaksanaan kegiatan.

\section{REFERENSI}

Akbar Riza Kurnia, 2017, Modul Elektronika dan Mekatronika Dasar Pneumatik, Direktorat Pembinaan Sekolah Menengah Kejuruan Komplek Kementerian Pendidikan dan Kebuadayaan, Gedung E, Lantai 13 Jalan Jenderal Sudirman, Senayan, Jakarta 10270

Priyonggo dan Hraiyanto, 2013, Peningkatan Pemahaman Mata Kuliah Pneumatik Dan Hidrolik Dengan Bantuan Movie Clip Macromedia Flash MX Multimedia Dan Bentuk Kerangka Model, JURNAL TEKNIK MESIN, TAHUN 21, NO.1

Saruna Mohammad Ikhsan, dkk, 2013, Analisis Sistem Penggerak Pneumatik Alat Angkat Kendaraan Niaga Kapasitas 2 Ton, Pradnya Paramita, Jakarta

Taribuka Semuel Marthen dan Hatuwe Azmain Noor, 2012, Perencanaan Instalasi Kontrol Pneumatik Menggunakan Metode Cascade Pada Alat Pelumatan Tanah Liat Sebagai Bahan Dasar Batu Bata Merah, Jurnal Teknologi, Volume 9 Nomor 1; 969-977 